\title{
Injury Responses to Different Surfactants in Ventilated Premature Lamb Lungs
}

\author{
MACHIKO IKEGAMI AND ALAN H. JOBE \\ Children's Hospital Medical Center, Division of Pulmonary Biology, Cincinnati, OH.
}

\begin{tabular}{|c|c|}
\hline \multicolumn{2}{|c|}{ ABSTRACT } \\
\hline $\begin{array}{l}\text { The lung of the preterm infant is easily injured and an initial } \\
\text { indication of the injury is an inflammatory response. Surfactant } \\
\text { treatment and gentle ventilation will minimize the initiation and } \\
\text { progression of injury. We asked if the initial lung injury response } \\
\text { differed when preterm ventilated lambs were treated with com- } \\
\text { plete natural sheep surfactant, a lipid extract of sheep surfactant, } \\
\text { a surfactant used to treat RDS (Survanta }{ }^{\circledR} \text { ), or a synthetic } \\
\text { surfactant containing recombinant SP-C (Venticute }{ }^{\circledR} \text { ). We used } \\
\text { a gentle style of ventilation and a positive end expiratory pres- } \\
\text { sure of } 4 \text { cm } \mathrm{H}_{2} 0 \text { to minimize injury. The surfactants were not } \\
\text { distinguishable based on gas exchange, compliance or lung gas } \\
\text { volumes over the } 6 \mathrm{~h} \text { ventilation period. When compared with } \\
\text { unventilated controls the ventilated lambs had increased protein } \\
\text { and inflammatory cells in alveolar lavages. The cells from the } \\
\text { alveolar lavages produced more } \mathrm{H}_{2} 0_{2} \text {, expressed more surface } \\
\text { adhesion antigens and CD- } 14 \text { receptors, and expressed more } \\
\text { mRNA for the pro-inflammatory cytokines IL- } 1 \beta \text { and IL- } 8 \text { than } \\
\text { did cells from unventilated lungs. Lung tissue expressed primar- } \\
\text { ily increased IL- } 6 \text { mRNA relative to unventilated controls. How- }\end{array}$ & $\begin{array}{l}\text { ever, there were no consistent differences in any of the inflam- } \\
\text { matory indicators between the different surfactant treated groups. } \\
\text { Because endotoxin free natural surfactant containing SP-A was } \\
\text { not superior to three other surfactants containing differing } \\
\text { amounts of the surfactant proteins, additions of these proteins to } \\
\text { clinical surfactants may not decrease the indicators of lung } \\
\text { inflammation that accompany the initiation of ventilation of the } \\
\text { preterm lung. (Pediatr Res 51: 689-695, 2002) } \\
\text { SP, surfactant protein } \\
\text { RDS, respiratory distress syndrome } \\
\text { BPD, bronchopulmonary dysplasia } \\
\text { S, surfactant } \\
\text { VT, tidal volume } \\
\text { PIP, peak inspiratory pressure } \\
\text { PEEP, positive end expiratory pressure } \\
\text { VEI, ventilatory efficiency index } \\
\text { Sat PC, saturated phosphatidylcholine }\end{array}$ \\
\hline
\end{tabular}

Surfactant treatment is standard care for infants with Respiratory Distress Syndrome (RDS). Surfactant treatment decreases morbidity and mortality; however, many surfactanttreated infants of low birth weight progress to bronchopulmonary dysplasia (BPD) (1). BPD is thought to be the end result of an inflammatory injury that interferes with lung development and injury repair in the very preterm lung (2). Airway samples from infants who develop BPD have increased numbers of pro-inflammatory cells and cytokines at birth or within the 1st days after birth (3). We previously reported that $2 \mathrm{~h}$ of mechanical ventilation of the preterm lamb lung induced recruitment of pro-inflammatory cells to the lungs and transcription of pro-inflammatory cytokines $(4,5)$. We

\footnotetext{
August 22, 2001; February 1, 2002.

Correspondence and reprint request: Machiko Ikegami, MD, PhD, Professor of Pediatrics, Children's Hospital Medical Center, Division of Pulmonary Biology, 3333 Burnet Avenue, Cincinnati, Ohio 45229-3039; e-mail: machiko.ikegami@chmcc.org

Grant HD-12714 from the National Institute of Health, Byk Gulden, Konstanz, Germany, provided Venticute ${ }^{\circledR}$; Ross Products Division, Abbott Laboratories, Inc., provided

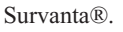

DOI: 10.1023/01.PDR.0000015912.88994.AB proposed that these early indicators of injury might promote the subsequent development of BPD.

Host defenses to injury are decreased in the preterm lung relative to the adult lung because the fetal preterm lung contains almost no mature macrophages or granulocytes and the innate host defense proteins SP-A and SP-D are low $(6,7)$. Antioxidant defenses also are low in the preterm (8). Part of the injury response to ventilation of the preterm lung may result from altered host defenses. Natural surfactant contains about $5 \%$ SP-A which can modulate inflammation and injury $(9,10)$. Surfactants used to treat infants are prepared by organic solvent extraction of surfactant recovered by alveolar lavage or from extracts of animal lungs. These surfactants contain variable amounts of the biophysically active proteins SP-B and SP-C but no SP-A. These surfactants are comparable for the treatment of RDS although there are some differences in short-term physiologic responses when the surfactants are tested in surfactant deficient preterm lungs (11-13). Different types of surfactant have been evaluated for physiologic indicators of injury such as lung mechanics, gas exchange and edema formation (13-15), but the different surfactants have not been 
evaluated for their effects on the early biochemical indicators of lung injury that have been identified in adult and preterm lungs $(5,16)$. We hypothesized that surfactants with different surfactant protein contents would induce different proinflammatory responses in the mechanically ventilated preterm lung. We treated premature lambs with natural sheep surfactant containing SP-A, B, C, an organic solvent extract of natural sheep surfactant that contains SP-B and SP-C, Survanta ${ }^{\circledR}$, a commercial surfactant containing bovine SP-C with a small amount of SP-B, or Venticute ${ }^{\circledR}$, a synthetic surfactant containing recombinant human SP-C and synthetic lipids. We evaluated local and systemic indicators of inflammation after treatment with the different surfactants at birth and after ventilation for $6 \mathrm{~h}$ and compared the measurements with unventilated fetal lung.

\section{METHODS}

Surfactant. Natural surfactant (Natural S) was recovered from saline lavages of adult sheep by centrifugation steps that isolate predominately the large-aggregate, highly surfaceactive fractions of surfactant (17). We used sterilized equipment and saline for intravascular use to avoid contamination. Extracted surfactant (Extracted S) was made from the sheep natural surfactant by chloroform-methanol (2:1) extraction (5). The extract was dried under nitrogen at $55^{\circ} \mathrm{C}$ and was suspended in saline with glass beads. The Natural S and Extracted $\mathrm{S}$ were negative for endotoxin by the Limulus amebocyte lysate assay (Sigma Chemical Co. Chemical Co., St. Louis, MO, U.S.A.). Survanta ${ }^{\circledR}$ (Ross Products, Columbus, OH, U.S.A.) was provided by the manufacturer and is currently widely used for treatment of infants with RDS. Venticute ${ }^{\circledR}$ (Byk Gulden, Konstanz, Germany) is synthetic surfactant which contains $2 \%$ recombinant human SP-C in dipalmitoylphosphatidylcholine and palmitoyl/oleoylphosphatidylglycerol in a 70:30 wt/wt ratio and 5\% palmitic acid. We previously found this surfactant to perform similarly to natural surfactant in preterm animals $(18,19)$. The concentration of the four surfactants was 25 $\mathrm{mg} / \mathrm{mL}$ and a dose of $4 \mathrm{~mL} / \mathrm{kg}$ was used.

Delivery and ventilation of preterm lambs. This study was approved by the Animal Ethics Committees at Children's Hospital Medical Center in Cincinnati, OH, U.S.A. Preterm lambs were delivered of Suffolk ewes at gestation age of $129 \mathrm{~d}$ to $132 \mathrm{~d}$ by cesarean section (term is $150 \mathrm{~d}$ ). These lambs have immature lungs and will not survive $6 \mathrm{~h}$ of ventilation unless treated with surfactant $(5,20)$. Five lambs were randomized to each surfactant treatment group and samples were collected from six fetuses of the same gestational ages that were not ventilated (unventilated comparison group). Each pregnant ewe was preanesthetized with ketamine $(10 \mathrm{mg} / \mathrm{kg}$ intramuscularly) and acepromazine $(0.3 \mathrm{mg} / \mathrm{kg})$, and then given spinalepidural anesthesia $(10 \mathrm{~mL}$ of $2 \%$ lidocaine and $0.5 \%$ bupivacaine $1: 1 \mathrm{vol} / \mathrm{vol}$ ) (18). After exposure of the head, the preterm lamb was given ketamine $(10 \mathrm{mg} / \mathrm{kg}$ intramuscularly) and acepromazine $(0.1 \mathrm{mg} / \mathrm{kg}$ intramuscularly) and intubated with a cuffed $4.5 \mathrm{~mm}$ tracheal tube. Lung fluid was removed from the tracheal tube by syringe aspiration and the trachea tube was occluded with a clamp. After the umbilical cord was cut, the lamb was weighed, and the randomly assigned surfactant $(4 \mathrm{~mL} / \mathrm{kg})$ was instilled into the fluid filled lung and ventilation was initiated. The initial ventilator settings were: fraction of inspired oxygen $\left(\mathrm{Fio}_{2}\right)=1.0$; respiratory rate 40 breaths $/ \mathrm{min}$; inspiratory time $0.7 \mathrm{~s}$; positive end expiratory pressure (PEEP) of $4 \mathrm{cmH}_{2} 0$, and a peak inspiratory pressure (PIP) sufficient to yield a tidal volume of $6 \mathrm{~mL} / \mathrm{kg}$ for the first 30 min of ventilation (18). Vт was monitored continuously (CP-100:Bicore Monitoring Systems, Anaheim, CA, U.S.A.). This low target for tidal volume was chosen to minimize lung injury with the initiation of ventilation (21). Peak inspiratory pressure and $\mathrm{FiO}_{2}$ was regulated to maintain target $\mathrm{Pco}_{2}$ of 55 $\mathrm{mm} \mathrm{Hg}$ and $\mathrm{P}_{2}$ of $150-200 \mathrm{~mm} \mathrm{Hg}$. A 5 French catheter was advanced into the aorta via an umbilical artery, and a $10 \mathrm{~mL} / \mathrm{kg}$ transfusion of filtered fetal blood collected from the placenta was administered within $10 \mathrm{~min}$ of delivery. VT was measured at $30 \mathrm{~min}, 1 \mathrm{~h}$ and every subsequent hour with a pneumotachometer. Dynamic compliance was calculated as VT normalized to body weight and divided by the ventilatory pressure, which is (PIP-PEEP). The ventilatory efficiency index (VEI) was calculated as $(\mathrm{VEI}=3,800 /$ respiratory rate $\times(\mathrm{PIP}-\mathrm{PEEP})$ $\times \mathrm{P}_{\mathrm{a}} \mathrm{CO}_{2}$ ), where 3,800 is a $\mathrm{CO}_{2}$ production constant (22). The arterial catheter was used for blood gas analysis, $\mathrm{pH}$ measurement, and blood pressure monitoring. Fluid containing 10\% dextrose was infused through a leg vein at the rate of 100 $\mathrm{mL} / \mathrm{kg} / \mathrm{d}$. Rectal temperature was monitored and kept at 38 to $39^{\circ} \mathrm{C}$ with heating pads and radiant heat. Supplemental ketamine and acepromazine were administered to suppress spontaneous breathing. After $6 \mathrm{~h}$, each animal was deeply anesthetized with $25 \mathrm{mg} / \mathrm{kg}$ pentobarbital I.V. The endotracheal tube was clamped for $3 \mathrm{~min}$ to permit oxygen absorption, and the animal was exsanguinated.

Pressure-volume curve and lung processing. The thorax of the lamb was opened, the lungs were inflated with air to 40 $\mathrm{cmH}_{2} 0$ pressure for $1 \mathrm{~min}$ and maximum lung volume was recorded (18). The pressure was sequentially lowered to 20,15 , 10,5 , and $0 \mathrm{cmH}_{2} 0$, and lung volumes were recorded after $30 \mathrm{~s}$ at each pressure. Volumes were corrected for the compliance of the system. Lungs were then removed from the thorax. Pieces of the right lower lobe were immediately frozen in liquid nitrogen for RNA isolation. Alveolar lavage of the left lung was with $0.9 \% \mathrm{NaCl}$ at $4{ }^{\circ} \mathrm{C}$, and the lavage was repeated five times (23). The lavage samples were pooled and aliquots were saved for measurement of saturated phosphatidylcholine (Sat PC), total protein, cell number and differential count, and flow cytometry.

Alveolar lavages were centrifuged at $500 \times g$ for $10 \mathrm{~min}$ and the pellet was resuspended in PBS. Cells were stained with tryptan blue and counted. Differential cell counts were performed on cytospin preparations after staining with Diff-Quick (American Scientific Products, San Diego, CA, U.S.A.). The activation state of the cells recruited to the airways was assessed by measuring hydrogen peroxide using an assay based on the oxidation of ferrous iron $\left(\mathrm{Fe}^{2+}\right)$ to ferric iron $\left(\mathrm{Fe}^{3+}\right)$ by hydrogen peroxide under acidic conditions (Bioxytech $\mathrm{H}_{2} \mathrm{O}_{2}-$ 560 Assay; 0XIS International, Portland, OR, U.S.A.).

Aliquots of alveolar cells were incubated on ice with $\mathrm{MAb}$ (primary antibody) against ovine $\mathrm{CD} 11 \mathrm{~b}(\alpha \mathrm{M}$ subunit of inte- 
grin CR3), CD14 (receptor for complex of lipopolysaccharide and lipopolysaccharide binding protein), and CD44 (proteoglycan link protein). The cell pellet was washed twice with PBS to remove unbound antibody, and was incubated with phycoerythrin (PE) labeled $\mathrm{F}\left(\mathrm{ab}^{\prime}\right)_{2}$ anti-IgG fragments (secondary antibody) in the dark on ice. Control staining was performed with isotype antibodies and with secondary antibody alone to obtain background fluorescence. Cells were washed twice, resuspended in PBS, kept on ice, and immediately analyzed on a fluorescence-activated cell sorter (FACS) (Calibur, BectonDickinson, Inc., Mountain View, CA, U.S.A.). All antibodies were from Serotec (Raleigh, NC, U.S.A.). Apoptotic cells and necrotic cells were detected by annexin $\mathrm{V}$ and propidium iodine staining (24) (Pharminger, Mountain View, CA, U.S.A.). Apoptotic and necrotic cells expose the inner cell membrane, allowing annexin $\mathrm{V}$ to bind to phosphatidylserine. Cell aliquots were stained with fluorescent-labeled annexin $\mathrm{V}$ and counterstained with proprium iodide to detect necrotic cells.

Cytokine mRNA. Total RNA was isolated from tissue from the right lower lobe and from cell pellets of the alveolar lavage samples by guanidinium thiocyanate-phenol-chloroform extraction. Ribonuclease protection assays were performed with total RNA from lung tissue and cell pellets (25). Briefly, RNA transcripts of ovine interleukins (IL-1 $\beta$, IL-6, IL-8, IL-10), tumor necrosis factor (TNF- $\alpha$ ), and ovine ribosomal protein L32 as a reference RNA were synthesized with $\left({ }^{32} \mathrm{P}\right)$ uridine triphosphate (Life Sciences Products, Boston, MA, U.S.A.) using SP6 or T7 polymerase (Ribonuclease Protection Assay 111: Ambion, Austin, TX, U.S.A.). Aliquots of $10 \mu \mathrm{g}$ RNA were incubated with excess radiolabeled probes for cytokines and $\mathrm{L} 32$ at $55^{\circ} \mathrm{C}$ for $18 \mathrm{~h}$. Remaining single-stranded RNA was digested with RNAse A/RNAse Ti (Ambion). Protected fragments were electrophoresed on a $6 \%$ polyacrylamide-urea sequencing gel and visualized by autoradiography. Densities of the protected bands were quantified on a PhosphorImager (Molecular Dynamics Inc., Sunnyvale, CA, U.S.A.), using ImageQuant Software (Molecular Dynamics).

mRNA for surfactant proteins and Sat PC. Surfactant protein mRNAs were measured using $\mathrm{S} 1$ nuclease protection assays as previously described (26). Briefly, an excess of linearized probes for ovine SP-A, SP-B, and SP-C and L32 that were $5^{\prime}$ end $\left({ }^{32} \mathrm{P}\right)$ labeled were hybridized at $56^{\circ} \mathrm{C}$ with $3 \mu \mathrm{g}$ of total RNA from lung tissue. SP-D was quantified in a separate assay with $10 \mu \mathrm{g}$ total RNA. The probe for SP-D was a kind gift of Dr. Hallman, University of Oulu, Finland. After incubation with $\mathrm{S} 1$ nuclease the protected fragments were resolved on $6 \%$ polyacrylamide 8 -mol urea sequencing gels, visualized by autoradiography and quantified on a phosphor imager (ImageQuant software, Molecular Dynamics Inc., Sunnyvale, CA, U.S.A.).

Saturated phosphatidylcholine (Sat PC) was isolated from chloroform-methanol (2:1) extracts of alveolar washes by neutral alumina column chromatography after exposure of lipid extracts to osmium tetroxide (27). Sat PC was quantified by phosphorus assay (28).

Lung morphology, inflammation score. The right upper lobe was inflation fixed with $10 \%$ formalin maintained at 30
$\mathrm{cmH}_{2} \mathrm{O}$ pressure. Paraffin tissue sections of $5 \mu \mathrm{m}$ thickness, stained with hematoxylin and eosin, were graded for the degree of inflammation by scoring three sections from each animal in a blinded fashion (29). The score was zero if there were no inflammatory cells in tissue or airspaces; 1 ) if a few cells were identified; 2) if moderate cell infiltration was present, and 3) if there were a large number of inflammatory cells in airspaces and tissue. Airspaces and tissue were assessed separately. Average scores were calculated for each animal.

Data analysis. Results are given as mean \pm SEM. Analysis of variance followed by the Student-Newman-Keuls multiple comparison procedures were used for comparisons of the four ventilated groups. Two-tailed unpaired $t$-tests were used for comparison with the unventilated group. Significance was accepted at $p<0.05$.

\section{RESULTS}

Physiologic outcome. The five lambs randomized to each group had similar mean birth weights of $3.4 \mathrm{~kg}$. The ventilation strategy was designed to minimize injury by using a tidal volume of about $6 \mathrm{~mL} / \mathrm{kg}$ over the first $30 \mathrm{~min}$ after delivery and then to increase the tidal volume to no more than $10 \mathrm{~mL} / \mathrm{kg}$ to achieve a target $\mathrm{PcO}_{2}$ of $55 \mathrm{~mm} \mathrm{Hg}$. This $\mathrm{Pco}_{2}$ was achieved with a mean tidal volume of $9.1 \mathrm{~mL} / \mathrm{kg}$ for all groups (Fig. $1 A$ ) using similar ventilatory pressures (Fig. 1B). No significant differences in oxygenation were found for the four surfactants, although oxygenation in the Venticute treated group tended to be lower (Fig. 1C). Dynamic compliances (Fig. 2A), the integrated evaluation of gas exchange measured by the VEI (Fig. $2 B$ ), and the deflation pressure volume curves (Fig. $2 C$ ) also were very similar for the four groups of lambs. These assessments demonstrate essentially equivalent responses of the lambs to treatment with the different surfactants over a $6 \mathrm{~h}$ period of ventilation.

Indicators of inflammation. Total protein was higher in the alveolar washes of all ventilated animals than for the unventilated animals (Fig. 3A). The inflammatory cells in alveolar washes were higher than for the unventilated lambs. The number of cells in the alveolar washes of the surfactant treated animals was similar as was the distribution of the inflammatory cells between lymphocytes, monocytes, and granulocytes (Fig. $3 B$ ). The $\mathrm{H}_{2} \mathrm{O}_{2}$ production by the cells from the alveolar washes also was not different, although $\mathrm{H}_{2} \mathrm{O}_{2}$ production was higher in all ventilated groups than the unventilated lungs where $\mathrm{H}_{2} \mathrm{O}_{2}$ was not detected (Fig. 3C). The intracellular adhesion molecule $\mathrm{CD}-11 \mathrm{~b}$ and the proteoglycan link protein CD-44 participate in the vascular to tissue migration of monocytes and neutrophils to sites of inflammation. Both antigens were detected on cells from the alveolar washes from the four surfactant treatment groups in similar amounts that were higher than for the unventilated animals when expressed as percent of cells (Table 1). The CD-14 receptor complex for lipopolysaccharide (LPS) and LPS binding protein was detectable in a low percentage of cells from all surfactant treated groups, and this percent was higher than for cells from unventilated lambs. The total fluorescence units also were similar for all measurements between the surfactant treated groups (data not shown). There were no 

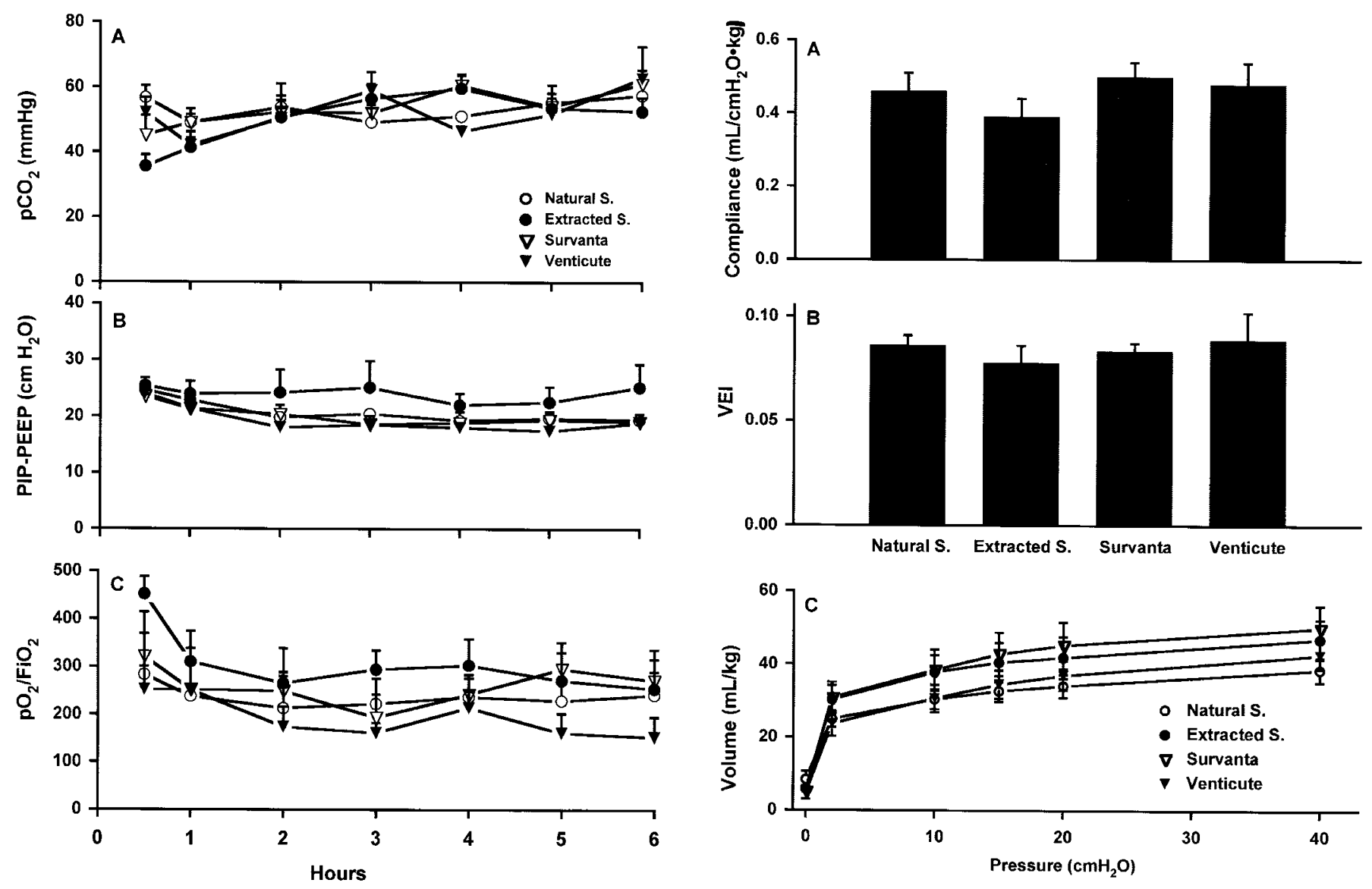

Figure 1. Sequential measurements of lung function in premature lambs treated with different surfactants. $(A) \mathrm{pCO}_{2}-$ The ventilation strategy was designed to minimize injury by using a tidal volume of $6 \mathrm{~mL} / \mathrm{kg}$ over the first $30 \mathrm{~min}$ which was then increased to $10 \mathrm{~mL} / \mathrm{kg}$ to achieve a target $\mathrm{pC}_{2}$ of 55 $\mathrm{mm} \mathrm{Hg}$. $(B)$ Ventilatory pressure (PIP-PEEP) - Similar ventilatory pressures were used for all four groups of lambs. $(C)$ Oxygenation was similar for the four surfactants.

differences in the percent of apoptotic cells in the alveolar washes of the surfactant treated groups (Table 1).

Cytokines in the lung. The pro-inflammatory cytokine $\mathrm{mR}-$ NAs for IL-6, IL-8 and TNF- $\alpha$ were increased in lung tissue relative to the amounts in the unventilated lungs (Fig. 4A). IL-1 $\beta$ mRNA was not increased and IL- 6 was increased about 6-fold relative to unventilated controls. The expression of IL-10 also was modestly increased in the lungs, but there were no differences for any of the surfactant treated groups. The pro-inflammatory cytokine mRNAs for IL- $1 \beta$, IL-6, and IL-8 were analyzed from cells recovered by alveolar lavage (Fig. $4 B$ ). Relative to cells from the unventilated control lavages, there were large increases in mRNA for IL- $1 \beta$ and IL- 8 , and no differences in surfactants were apparent. In contrast to mRNA from lung tissue, mRNA for IL-6 was not increased.

Inflammatory index. The inflammatory index measured on histologic sections from the right upper lobes averaged 1.3 in both the airspaces and the tissue indicating that a few inflammatory cells were apparent by histology (Fig. 5). The only statistical differences in airspace inflammatory index were between unventilated lambs and Natural S and Survanta group

Figure 2. (A) Dynamic lung compliance at $6 \mathrm{~h}$ of age. $(B)$ The integrated evaluation of gas exchange measured by ventilation efficiency Index (VEI) after $6 \mathrm{~h}$ of ventilation. $(C)$ Deflation limbs of pressure-volume curves. After $6 \mathrm{~h}$ of ventilation there were no significant differences in lung function on lung volumes.

and these differences were not large $(p<0.05)$. There were no indicators of lung injury such as edema, interstitial emphysema, or alveolar hemorrhage.

Surfactant. The mRNAs for the surfactant proteins were expressed relative to the amounts measured for the unventilated lungs (Fig. 6). There were no differences in mRNAs for SP-A, SP-B, SP-C or SP-D in any of the ventilated groups. The percent of the Sat PC contained in each surfactant that was recovered by alveolar wash was not different between the surfactant treated groups.

\section{DISCUSSION}

We asked if the physiologic responses and indicators of injury in ventilated preterm lambs differed for Natural $\mathrm{S}$, an extract of natural surfactant that lacks SP-A and other nonsurfactant specific proteins and perhaps other factors, a surfactant made from bovine lung that is widely used clinically, and a synthetic surfactant containing only synthetic lipids and recombinant SP-C. We treated with surfactant before mechanical ventilation, and we used a gentle ventilation strategy to avoid lung injury as much as possible $(21,30)$. We used a PEEP of $4 \mathrm{cmH}_{2} 0$ that was previously shown to cause less lung injury in preterm lambs than a PEEP of 0 or $7 \mathrm{cmH}_{2} 0$ (18). The tidal 

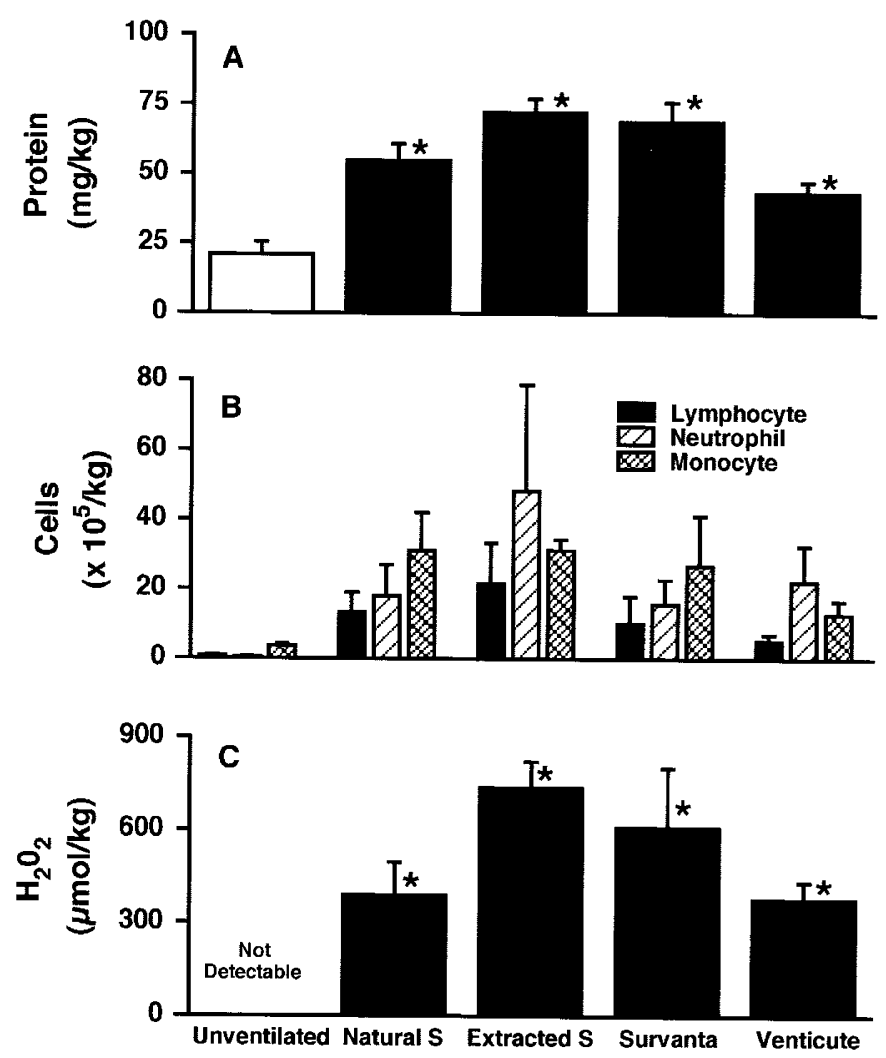

Figure 3. (A) Total protein in the alveolar washes were higher in all ventilated animals than the unventilated animals. $(B)$ The number of cells in the alveolar washes of the surfactant treated animals was similar as was the distribution of the inflammatory cells. $(C)$ The $\mathrm{H}_{2} \mathrm{O}_{2}$ production by the cells from the alveolar washes was similar between four surfactant groups and was higher than unventilated group where $\mathrm{H}_{2} \mathrm{O}_{2}$ was not detected. * $p<0.05$ vs unventilated group.

Table 1. Flow cytometric analysis of cells from alveolar lavage sample

\begin{tabular}{lcccr}
\hline & \multicolumn{4}{c}{ \% Cells Expressing Antigen } \\
\cline { 2 - 5 } & CD11b & CD44 & CD14 & \multicolumn{1}{c}{$\begin{array}{c}\text { Apoptotic } \\
\text { Cells }\end{array}$} \\
\hline Unventilated & $1.1 \pm 0.1^{*}$ & $1.0 \pm 0.1^{*}$ & $0.8 \pm 0.1^{*}$ & $13.1 \pm 2.2$ \\
Natural S. & $15.0 \pm 5.9$ & $13.1 \pm 2.5$ & $9.8 \pm 4.0$ & $10.4 \pm 7.2$ \\
Extracted S. & $7.3 \pm 1.1$ & $7.9 \pm 1.5$ & $5.2 \pm 0.8$ & $2.9 \pm 1.7$ \\
Survanta & $18.8 \pm 11.4$ & $7.3 \pm 1.2$ & $6.3 \pm 0.5$ & $10.6 \pm 5.0$ \\
Venticute & $5.4 \pm 1.3$ & $6.8 \pm 1.2$ & $5.8 \pm 0.6$ & $5.2 \pm 1.3$ \\
\hline
\end{tabular}

$* p<0.05$ vs Others.

volume goals were higher than often used in humans, but lower tidal volumes in preterm lambs cause severe hypocarbia (21). The total lung capacity was about $40 \mathrm{~mL} / \mathrm{kg}$, indicating that tidal volume did not approach total lung capacity. Despite the differences in surfactant composition, lung function and indicators of injury were very similar across all ventilated groups. However, the ventilated groups had multiple indicators of an initiation of an injury response relative to unventilated lungs.

The results need to be interpreted in the context of previous information about how the adult and preterm lung can be injured. If lungs are overdistended with the initiation of ventilation, then surfactant responses are poor, alveolar protein is high and lung injury is obvious histologically $(21,31)$. Surfactant treatment and ventilation with a PEEP of $4 \mathrm{cmH}_{2} \mathrm{O}$ pre-
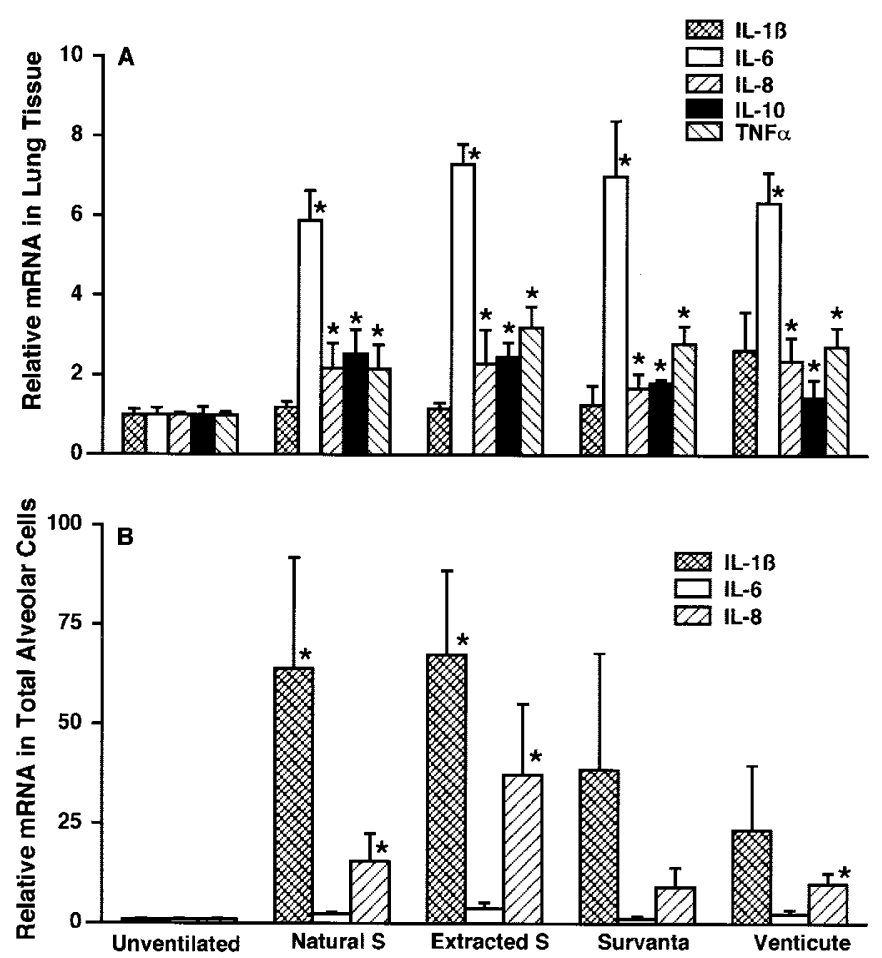

Figure 4. Cytokine mRNA. (A) IL-6, IL-8, IL-10 and TNF- $\alpha$ mRNAs were increased in lung tissue relative to the unventilated lungs. IL- 6 had the highest increase in the ventilated groups relative to unventilated lambs. (B) Alveolar Cells. Large increases were seen in mRNA for IL-1 $\beta$ and IL-8. ${ }^{*} p<0.05 v s$ unventilated group.

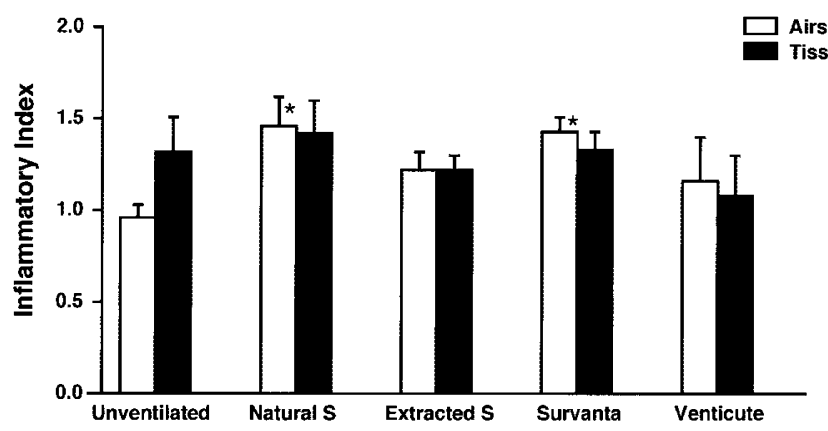

Figure 5. Inflammatory index in airspace and lung tissue. There were a few inflammatory cells identified by histology in airspace. ${ }^{*} p<0.05 v s$ unventilated group.

vents most of the severe acute injury (18). Lambs at this gestation will have severe progressive respiratory failure and die despite mechanical ventilation unless treated with surfactant (20). The surfactant pool from the alveolar washes of the control lambs contained only $0.57 \pm 0.26 \mu \mathrm{mol} / \mathrm{kg}$ Sat PC and $18 \pm 7 \mathrm{ng} / \mathrm{kg}$ SP-A, which is $0.9 \%$ of newborn lamb surfactant pool size (32), indicating severe surfactant deficiency. The four surfactants were equivalently effective for $6 \mathrm{~h}$ after preterm birth. Relative to preterm fetal lungs, the lungs of these surfactant treated lambs had increased amounts of total protein, increased numbers of inflammatory cells, and increased cytokine mRNA expression in the lung tissue and cells from alveolar washes (5). However, these values were lower than for preterm lungs that were intentionally injured by ventilation with no PEEP or by intratracheal endotoxin $(5,33)$. Neverthe- 


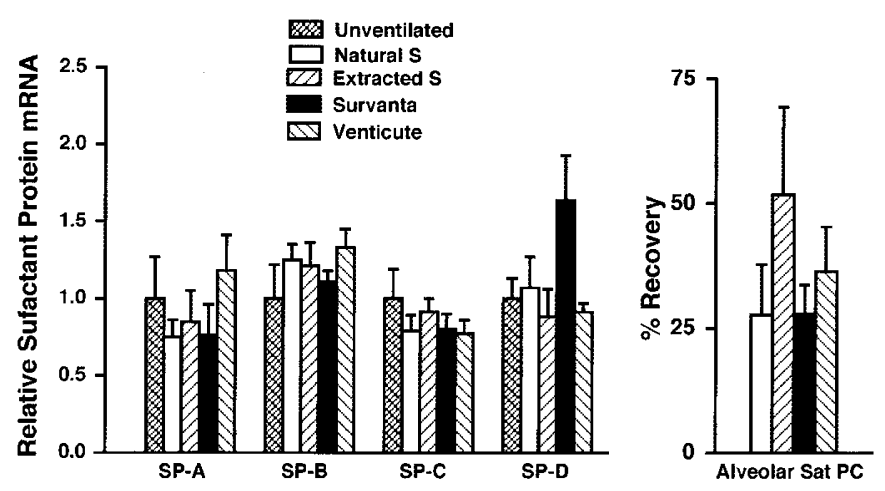

Figure 6. Surfactant Protein mRNA and Saturated phosphatidylcholine (Sat PC). Intensity of hybridization of mRNA was related to that of L32 mRNA, a ribosomal protein mRNA, and normalized to the value for unventilated group which was given a value of 1 . There are no differences between groups. Percent recoveries of Sat PC in alveolar lavages are shown on the right side of the figure. There were no differences between groups for the recovery of exogenous surfactant after $6 \mathrm{~h}$ of ventilation.

less, ventilation of preterm lambs treated with the synthetic SP-C containing surfactant, or the clinical surfactant Survanta, did result in increased inflammatory cell and cytokine expression relative to the fetal lung (5). We hypothesized that natural surfactant might promote less injury because it would contain more of the surfactant proteins or host defense components. We used a complete natural sheep surfactant that was endotoxin free and an organic solvent extract surfactant and found equivalent indicators of inflammation. These results suggest that adding components present in natural surfactant to the surfactants used clinically is unlikely to improve their antiinflammatory characteristics against lung injury by ventilation.

These results can be interpreted in two ways: the increased inflammatory indicators simply reflect normal neonatal adaptation, or the inflammation is an injurious process that, if it persists, can progress to acute lung injury and subsequently BPD (34). Infants who subsequently develop BPD have inflammatory cells and cytokines in samples from the airways that are higher than the same indicators from the airways of infants that do not develop BPD $(3,35)$. Some inflammation may be inevitable with ventilation and oxygen exposure. The progressive nature of the injury may be the critical factor. Surfactant treated and ventilated preterm lambs and baboons develop BPD characterized by an arrest in alveolar development $(36,37)$. That pathology is associated with persistent elevations of pro-inflammatory cytokines in the lungs (37).

We previously hypothesized that the lack of SP-A in the preterm lung would tend to promote inflammation because SP-A binds endotoxin, multiple pathogens, and down-regulates inflammation $(9,10)$. However, addition of sheep SP-A to the recombinant SP-C surfactant resulted in more rather than less inflammation in ventilated premature lamb lung (20). The equivalent inflammation in lambs treated with Natural S containing SP-A and Extract S that lacks SP-A contradict that result. We have no explanation for the difference except to speculate that the isolation and purification of SP-A may alter aggregate forms of SP-A to yield products that are inflammatory. Perhaps the message is that caution is appropriate when synthetic or purified surfactant components are used to treat the preterm lung. SP-A as part of natural surfactant was not pro-inflammatory, while purified SP-A added to synthetic surfactant was pro-inflammatory (20).

An interesting finding is the difference in cytokine mRNA expression in the total lung and in the cells recovered by alveolar lavage. The increases in mRNA for the proinflammatory cytokines IL- $1 \beta$, IL- 8 , and TNF- $\alpha$ in lung tissue after $6 \mathrm{~h}$ ventilation was only 2 - to 3 -fold above the low levels measured in fetal lung, and the increase in the mRNA for the anti-inflammatory cytokine IL-10 was of a similar magnitude. The largest increases of about 6-fold were for IL-6 in lung tissue, and no increase in IL-1 $\beta$ was noted in the lung tissue. In contrast the cells recovered by alveolar lavage had 20- to 70-fold increases in IL-1 $\beta$ and 10- to 30 -fold increases in IL-8 with no change in IL-6 mRNA. The cytokine products of the alveolar cells differ from those of the lung as a whole, and the relative amplification of the mRNAs for IL- $1 \beta$ and IL- 8 are much higher in the alveolar cells. However, our results indicate that the source of the IL-6 may be the tissue rather than the inflammatory cells recruited to the lungs. Transgenic mice that over-express IL-6 are more resistant to oxidant injury than normal mice, indicating that increases in IL- 6 may be beneficial (38). There is no information about IL-6 function in the preterm lung.

Surfactant treatments did not alter the mRNAs for the surfactant proteins after $6 \mathrm{~h}$ ventilation. We previously reported SP-A and SP-C mRNAs increased in natural surfactant treated preterm lungs (39). A caveat to those observations is that we now know that natural surfactant is commonly contaminated with endotoxin unless extreme care during isolation is taken. Endotoxin promotes an inflammatory response in the fetal sheep lung that results in increased mRNAs for all of the surfactant proteins (26). The low-grade inflammation resulting from gentle ventilation of these lambs did not result in increases in surfactant protein mRNA within $6 \mathrm{~h}$. The inflammatory indicators were similar for the four different surfactants that we tested. These experiments are of low resolution to detect small differences in either physiologic responses or indicators of injury because of the small number of animals in each treatment group. However, the overall consistency of the data suggests large differences are unlikely. Modifications of surfactants to minimize lung injury in the preterm may be a less effective strategy than the development of strategies to minimize the injury caused by mechanical ventilation.

Acknowledgments. The authors thank Shawn Grant and Maura Unger for their excellent technical assistance.

\section{REFERENCES}

1. Charafeddine L, D'Angio CT, Phelps DL 1999 Atypical chronic lung disease patterns in neonates. Pediatrics 103:759-765

2. Jobe A, Bancalari E 2001 NICHD/NHLBI/ORD Workshop Summary - Bronchopulmonary Dysplasia Am J Respir Crit Care Med 163:1723-1729

3. Speer CP, Groneck P 1998 Oxygen radicals, cytokines, adhesion molecules and lung injury in neonates. W.B. Saunders, Philadelphia, pp 219-228

4. Ikegami M, Kallapur S, Michna J, Jobe A H 2000 Lung injury and surfactant metabolism after hyperventilation of premature lambs. Pediatr Res 47:398-404

5. Naik AS, Kallapur SG, Bachurski CJ, Jobe AH, Michna J, Kramer BW, Ikegami M 2001 Effects of ventilation with different positive end-expiratory pressures on cytokine expression in the preterm lamb lung. Am J Respir Crit Care Med 164:494-498 
6. Jackson JC, Chi EY, Wilson CB, Truog WE, Teh EC, Hodson WA 1987 Sequence of inflammatory cell migration into lung during recovery from hyaline membrane disease in premature newborn monkeys. Am Rev Respir Dis 135:937-940

7. Marshall-Clarke S, Reen D, Tasker L, Hassan J 2000 Neonatal immunity: how well has it grown up? Immunol Today 21:35-41

8. Walther FJ, Jobe AH, Ikegami M 1998 Repetitive prenatal glucocorticoid therapy reduces oxidative stress in the lungs of preterm lambs. J Appl Physiol 85:273-278

9. Wright JR 1997 Immunomodulatory functions of surfactant. Physiol Rev 77:931-962

10. Mason RJ, Greene K, Voelker DR 1998 Surfactant protein A and surfactant protein $\mathrm{D}$ in health and disease. Am J Physiol 275:L1-L13

11. Mizuno K, Ikegami M, Chen CM, Ueda T, Jobe AH 1995 Surfactant protein-B supplementation improves in vivo function of a modified natural surfactant. Pediatr Res 37:271-276

12. Bloom BT, Kattwinkel J, Hall RT, Delmore PM, Egan EA, Trout JR, Malloy MH, Brown DR, Holzman IR, Coghill CH, Carlo WA, Pramanik AK, McCaffree MA, Toubas PL, Laudert S, Gratny LL, Weatherstone KB, Seguin JH, Willett LD, Gutcher GR, Mueller DH, Topper WH 1997 Comparison of Infasurf (calf lung surfactant extract) to Survanta (Beractant) in the treatment and prevention of respiratory distress syndrome. Pediatrics 100:31-38

13. Cummings JJ, Holm BA, Hudak ML, Hudak BB, Ferguson WH, Egan EA 1992 A controlled clinical comparison of four different surfactant preparations in surfactantdeficient preterm lambs. Am Rev Respir Dis 145:999-1004

14. Ikegami M, Agata Y, Elkady T, Hallman M, Berry D, Jobe A 1987 A comparison of four surfactants: in vitro surface properties and responses of preterm lambs to treatment at birth. Pediatrics 79:38-46

15. Hafner D, Beume R, Kilian U, Krasznai G, Lachmann B 1995 Dose-response comparisons of five lung surfactant factor (LSF) preparations in an animal model of adult respiratory distress syndrome (ARDS). Br J Pharmacol 115:451-458

16. Tremblay LN, Slutsky AS, Dreyfuss D, Saumon G 1998 Ventilator-induced lung injury: Mechanisms and clinical correlates. Marcel Dekker, Inc., New York, pp 395-451

17. Ueda T, Ikegami M, Jobe AH 1994 Surfactant subtypes: In vivo function, and effects of serum proteins. Am J Respir Crit Care Med 149:1254-1259

18. Michna J, Jobe AH, Ikegami M 1999 Positive end-expiratory pressure preserves surfactant function in preterm lambs. Am J Respir Crit Care Med 160:634-639

19. Davis AJ, Jobe AH, Häfner D, Ikegami M 1998 Lung function in premature lambs and rabbits treated with a recombinant SP-C surfactant. Am J Respir Crit Care Med 157:553-559

20. Kramer BW, Jobe AH, Bachurski CJ, Ikegami M 2001 Surfactant protein A recruits neutrophils into the lungs of ventilated preterm lambs. Am J Respir Crit Care Med 163:158-165

21. Wada K, Jobe AH, Ikegami M 1997 Tidal volume effects on surfactant treatment responses with the initiation of ventilation in preterm lambs. J Appl Physiol 83:10541061

22. Notter RH, Egan EA, Kwong MS, Holm BA, Shapiro DL 1985 Lung surfactant replacement in premature lambs with extracted lipids from bovine lung lavage: effects of dose, dispersion technique, and gestational age. Pediatr Res 19:569-577
23. Jobe A, Ikegami M, Jacobs H, Jones S, Conaway D 1983 Permeability of premature lamb lungs to protein and the effect of surfactant on that permeability. J Appl Physiol 55:169-176

24. Vermes I, Haanen C, Steffens-Nakken H, Reutelingsperger C 1995 A novel assay for apoptosis. Flow cytometric detection of phosphatidylserine expression on early apoptotic cells using fluorescein labelled Annexin V. J Immunol Methods 184:39-51

25. Kallapur SG, Willet KE, Jobe AH, Ikegami M, Bachurski C 2001 Intra-amniotic endotoxin: Chorioamnionitis precedes lung maturation in preterm lambs. Am J Physiol 280:L527-L536

26. Bachurski CJ, Ross GF, Ikegami M, Kramer BW, Jobe A H 2001 Intra-amniotic endotoxin increases pulmonary surfactant components and induces SP-B processing in fetal sheep. Am J Physiol 280:L279-L285

27. Mason RJ, Nellenbogen J, Clements JA 1976 Isolation of disaturated phosphatidylcholine with osmium tetroxide. J Lipid Res 17:281-284

28. Bartlett GR 1959 Phosphorus assay in column chromatography. J Biol Chem 234:466-468

29. Willet K, Jobe A, Ikegami M, Brennan S, Newnham J, Sly P 2000 Antenatal endotoxin and glucocorticoid effects on lung morphometry in preterm lambs. Pediatr Res 48:782-788

30. Carlton DP, Cho SC, Davis P, Lont M, Bland RD 1995 Surfactant treatment at birth reduces lung vascular injury and edema in preterm lambs. Pediatr Res 37:265-270

31. Bjorklund LL, Ingimarsson J, Curstedt T, John J, Robertson B, Werner O, Vilstrup CT 1997 Manual ventilation with a few large breaths at birth compromises the therapeutic effect of subsequent surfactant replacement in immature lambs. Pediatr Res 42:348-355

32. Ueda T, Ikegami M, Jobe AH 1994 Developmental changes of sheep surfactant: in vivo function and in vitro subtype conversion. J Appl Physiol 76:2701-2706

33. Kramer BW, Ikegami M, Jobe A 2001 Intratracheal endotoxin causes systemic inflammation in ventilated preterm lambs. Am J Respir Crit Care Med (in press)

34. Jobe AH, Ikegami M 2001 Prevention of bronchopulmonary dysplasia. Curr Opin Pediatr 13:124-129

35. Watterberg KL, Demers LM, Scott SM, Murphy S 1996 Chorioamnionitis and early lung inflammation in infants in whom bronchopulmonary dysplasia develops. Pediatrics 97:210-215

36. Albertine KH, Jones GP, Starcher BC, Bohnsack JF, Davis PL, Cho S, Carlton DP, Bland RD 1999 Chronic lung injury in preterm lambs. Am J Respir Crit Care Med 159:945-958

37. Coalson JJ, Winter VT, Siler-Khodr T, Yoder BA 1999 Neonatal chronic lung disease in extremely immature baboons. Am J Respir Crit Care Med 160:1333-1346

38. Ward NS, Waxman AB, Homer RJ, Mantell LL, Einarsson O, Du Y, Elias J A 2000 Interleukin-6-induced protection in hyperoxic acute lung injury Am J Respir Cell Mol Biol 22:535-542

39. Woods E, Ohashi T, Polk D, Ikegami M, Ueda T, Jobe AH 1995 Surfactant treatment and ventilation effects on surfactant SP-A, SP-B, and SP-C mRNA levels in preterm lamb lungs. Am J Physiol-Lung Cell Mol Physiol 13:L209-L214 